\title{
Japan and the War
}

\section{What the Mikado's Navy Has Done for the Allied Cause \\ By Adachi Kinnosuke}

$\mathrm{W}^{\mathrm{HAT}}$ has the Japanese navy done, what is it doing, for the cause of the Entente Allies? The question is getting both fashionable and a bit persistent. It is quite natural that it should be so; these are the days when the Britisher is actually wondering what the British Navy is doing and the American is showing some impatience in finding out just what it is that the American navy is doing.

And as though in answer to the query-not many weeks ago the Japanese light cruiser, "Akashi" steamed

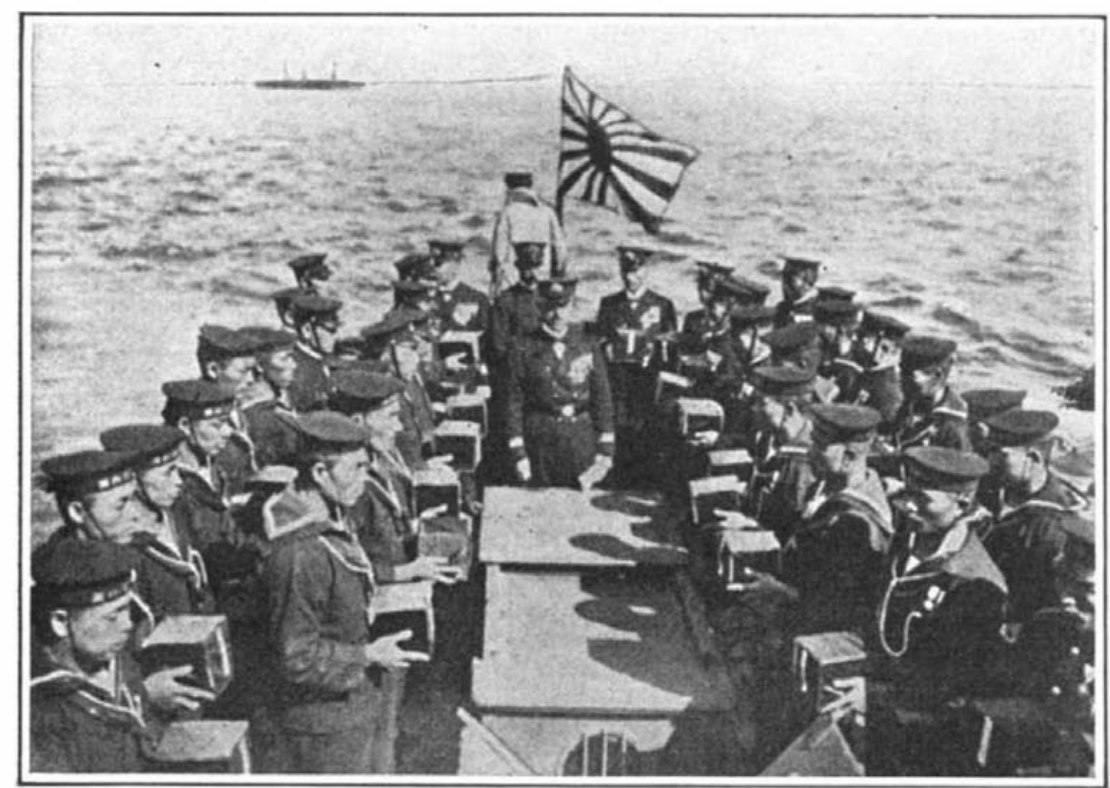
Bodies of first Japanese submarine rictims entering port at the
naval base of Yokosuka

into the naval port of Yokosuka. She had returned from the Mediterranean. Aboard her she had brought home the remains of Captain Uehara and his men who had lost their lives when the Destroyer "Sakaki" was torpedoed by a U-boat. That was news to the people of Nippon. For the landing of the remains of the "Sakaki's" commander and his men was about the first pointed hint they had had of the war activity of the Japanese navy in European waters.

Since then, the Cruiser "Hirato" has also reported home at Yokosuka. She had been in continuous service for nine months, and had steamed over twenty-six thousand knots. And according to her officers most of that was over pretty stormy waters-her deck of ten under three feet of sea, while pitching up 35 degrees was such a common experience with her men that they simply said nothing and got used to the thing.

The "Niitaka," another light cruiser, came home after the "Hirato." And the performance of the "Niitaka" has completely eclipsed the feats of the "Hirato." For the "Niitaka" had been out for two years. She had left the naval base at Sasebo in the early days of December, 1915, and had been in continuous service ever since. She had steamed altogether over fifty thousand knots-equivalent to more than twice the circumference of the globe.

Both the "Niitaka" and the "Hirato" have been out on patrol duty-keeping the sea lane from the Far Eastern ports to Suez not only open, but safe from the German raiders. Their work has been unnoted and unsung. They seem to count it lucky that they did not, like Gray's gem of purest ray serene, end by adorning some dark unfathomed cave of ocean. But from the way their men talk, the German raiders were about the easiest enemy they had to contend with. Typhoons, monsoons and other moods of the temperamental South Pacific and Indian Oceans were much worse. But the worst storms encountered were as nothing compared to the laughs of the swivel chair critics at home and abroad Such critics can patrol the sea lane from Sydney to Suez in a sentence of ten words: naturally they don't think it much of a job. The newspaper readers read the sentence in half a second; they think of it even less than does the erudite author. But to the men and ships of the Nippon navy who measure the sea at 10 and 15 knots an hour, it looks entirely different-this business of patroling the 6,000-mile path through the world's wildest waters, from Sydney to Aden. This task is anythin but a joke, anything but a sinecure, when the crew is rolling and staggering through three feet of water above deck, with the captain on the bridge looking like drowned rat.

When that famous German raide "Emden' was having her little game with the merchantmen to the tune of 20 ships and $\$ 20,000,000$, the query, "Where's the Japanese Navy?" was persistent enough to get on the nerves of the men of the Nippon navy. When the raide was at last sent to the place whence she will never come -not by a ship of the Japanese navy but by a modest little Australian cruiser-the query turned into a laugh. It was not a pleasant laugh in anybody's ears, more especially so not in the ears of the men of the Imperial Japanese navy. The world laughed at themthen. All that has changed a little since.

When the commander of the Japanese squadron which convoyed the British Colonial troop ships all the way from British navy said nice things to him, gave him a little silve trophy as the token of their high appreciation of his work, and told himat a public banquet that it was due entirely to the work of the Japanese navy that the Australian cruiser," "Sydney," was able to get on the track of the "Emden" and sink her off Cocos Island-because if the Japanese ships had not covered so well the route through the Indian Ocean and the South Pacific, the Australian cruiser would never have been able to chase the German raider to its final destruction. The same could

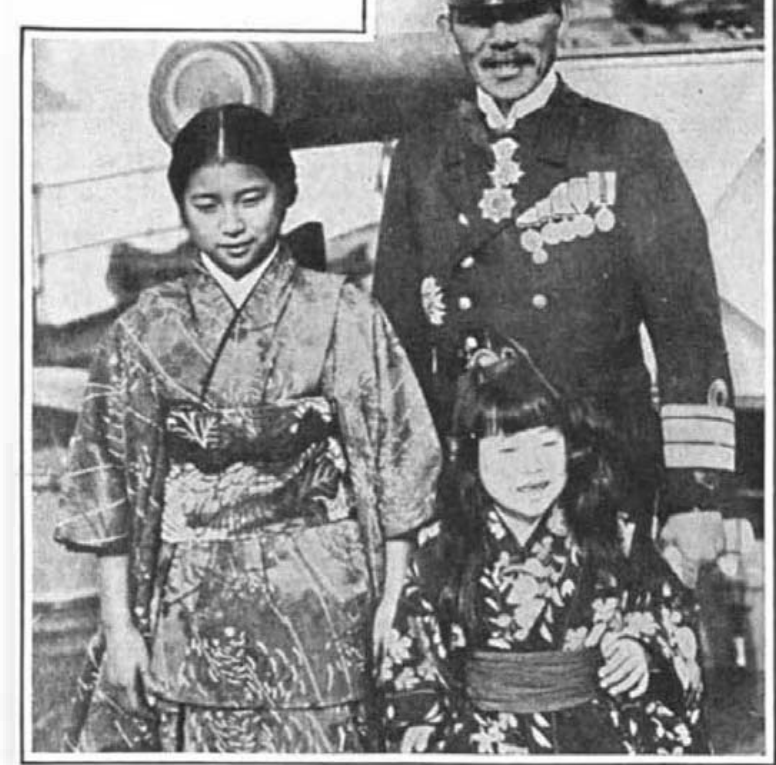

Rear Admiral Yamaji of the Japanese scouting squadron and his daughters

be said of the destruction of the Germanfleet under Admiralvon Spee off the South American coast by a British fleet.

But all this work of the Japanese navy in patroling the $\mathrm{Pa}$ cific and keeping the sea lane open from the Far Eas Europe has been publishedfrom time to time-likewise the part the Navyplayedindriving Germanyfrom her Far Easternbase at Kiauchau. What the Ameriican public has not heard so much of is what the Japanese navy has been doing to help France and the other Entent navies in the waters of Europe.

Rear Admiral Moriyama made a statement recently about what the Japanese navy has done in furnishing new destroyers to the French navy. That was entirely a bit of news to most of his own countrymen and doubtless so to the general public of Europe and the United States. The Admiral's remark had no reference to the Japanese destroyer and cruiser squadron under the command of Rear-Admiral Sato which is fighting U-boats in the Mediterranean in coöperation with the ships. of the Entente navies. He meant that the Japanese navy yard had built a number of destroyers for the use of the.French navy. He did not specify the exact number-he merely indicated that it was more than ten. And according to the same high authority, the Japanese navy did more than build these destroyers for the French navy. When they were ready for service they were delivered-the men of the Japanese navy took them from a Japanese port clear over to the French waters.

Not so many weeks ago, one of the sons of an exPresident of the United States was aboard an American transport making for a French port. The ship was passing through a danger zone. The ex-President's son and his comrades noticed that the transport was being convoyed by warships. What they did not expect to see was the flag of the Japanese navy; but it was there just as red and just as white as ever. The sight was something of a shock-decidedly pleasant to the exPresident's son as the story goes. It seems to have sent the first definite realization that Japan is in fact one of the fighting allies in this great world war.

But when the Japanese navy turns to thoughts of Russia, then a wistful shadow falls athwart its war reflections. For after all, it is neither France nor the British Empire to which the Japanese navy has devoted its greatest efforts. From the very opening of the war Russia claimed its prime and instant attention. As soon as Japan entered the war on the side of the Entente Allies, the Japanese navy sold back to Russia three ships of war which it had captured from her in the war of 1905 - the battleship "Sagami," the "Peresviet" of Russian memory, of 12,674 tons; the battleship "Tango" of 10,960 which once was the Russian Poltava, and the famous "Variag" renamed "Soya." These ships had been almost completely rebuilt and refitted since they had been captured from Russia, and so improved that they were very far from being a lot of antiquated tubs rich only in heroic memories. The Japanese did very well in selling them over to Russia; for it was at once a very graceful act and, from the standpoint of the Entente cause, an effective one. It wiped off the last restige for Russia of the humiliating memory of the Russo-Japanese war, and at the same time added three good ships ready and fitted for instant service under the Russian flag.

But of course selling the three ships was a mere preliminary bow of courtesy. The real service which the Japanese navy rendered to Russia was in freeing her entire Pacific fleet from any further war duties and especially from any duties in connection with the guarding of the line of communications and supplies from Japan and the United States. It has even been said that the Japanese navy so far forgot its dignity in its eager desire to serve its Russian ally that it even played the good natured errand boy and brought the Russian gold all the way across the Pacific to a North American

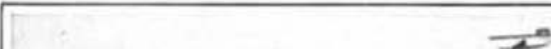

a.
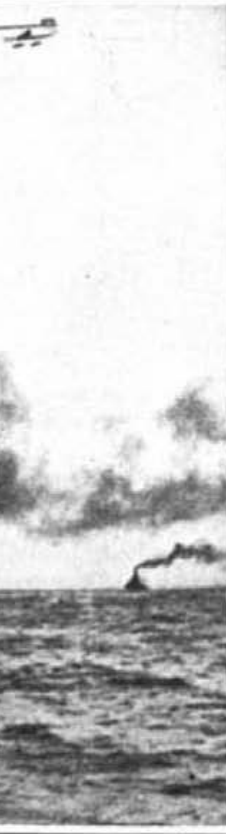

"Hirato" retarning to Yokosuka after nine month

"Wurato" returning to Yokosuka after

port. And while the present state of Russia is quite enough to make her friends shake their heads more or less gently, even so, the Japanese navy does not seem to take the view that all its past arduous efforts in Russia's behalf are altogether in vain.

\section{Cambridge Observatory in the War}

THE staff of the observatory of Cambridge University has been reduced to one member-the directorthe loss of his two assistants in the war. Mr. Hartley, first assistant was killed on the "Vanginard" last summer, and Mr. F. Entwistle, second assistant; was recently killed in France where he was serving as a lieutenant in the Norfolk Regiment. 


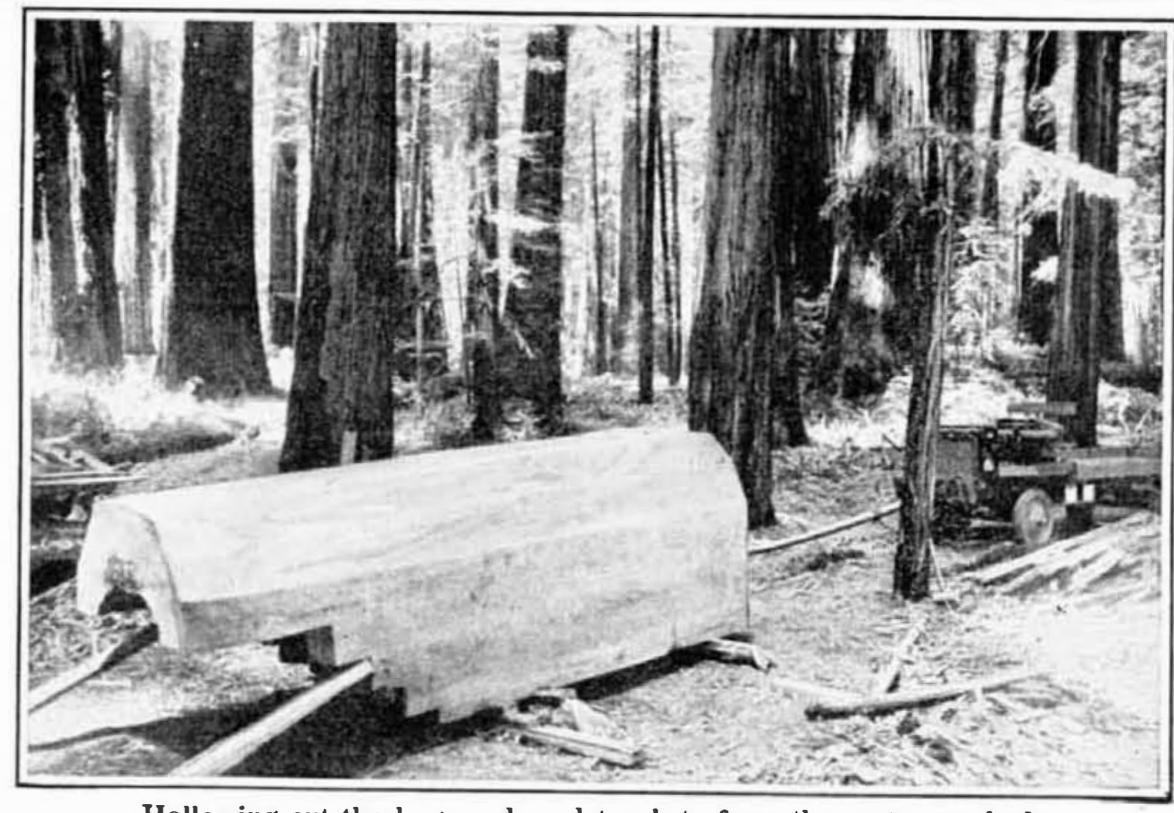

Hollowing out the huge redwood trunk to form the motor-car body

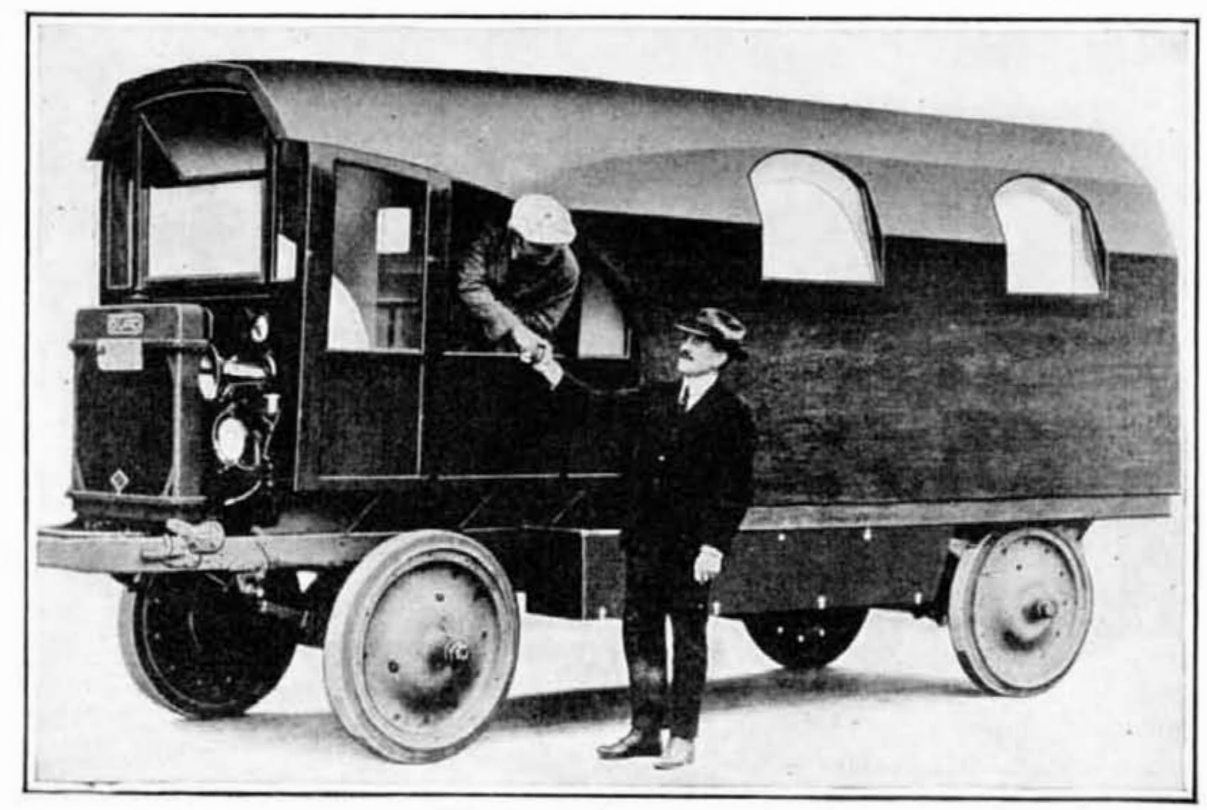

The finished car in service
An Automobile Body in One Piece

HERE is the story of the modern tree man. He lives

$\mathrm{ERE}$ is the story of the modern tree man. He lives plate glass windows. The body of the car is 19 feet long
in the trunk of a huge redwood tree mounted on and contains three rooms, each six feet square; a living

top of a motor truck, and travels about the country room, a bedroom and the chauffeur's room. The rooms enjoying practically all the comforts of a three-room apartment. First cutting a 22-foot section from a fallen redwood, 360 feet long and 11 feet in diameter, he proceeded to fashion the huge piece of timber into an automobile body which has no counterpart in this or any other country. Mr. Charles Kellogg of Santa Clara County, California, is the owner and builder of this remarkable vehicle. The tree from which the body was made was a fallen monarch that had been lying on the ground for perhaps a hundred years without any sign of decay. As a matter of fact, the wood was found to be full of sap and alive notwithstanding that the tree had been uprooted for a century. The 22-foot section when first cut-a 14-foot saw being used for the purpose-weighed approximately forty tons.

The first step after the section had been cut was to remove the bark. Then the task of hollowing out the trunk was begun. This was found to be most difficult. A couple of expert axemen first attacked it, but at the end of three days were worn out and gave up the job. Oxy-acetylene was then tried, but this also failed, as the redwood proved impervious to the flame, the wood carbonizing in a wall.

Mr. Kellogg then put some of his own ideas into operation. He first drove a gas pipe through the heart of the log, using the truck on which the body was to be mounted as a battering ram. This small aperture was enlarged by a pepper wood chisel fastened to the front of the truck with chains. Then the hollowing out process was completed with a 22 -foot chisel operated in the same manner. This left a shell one foot thick and Mr. Kellogg trusted to his eye alone in smoothing out the log and modeling it are all luxuriously furnished, a feature of the living room as a sculptor would into a beautifully shaped body.

As the shell in its unfinished state weighed in thro neighor sood 6,000 pounds, the problem of mounting it on the truck was a difficult one. This was finally solved by cribbing the corners with slabs and digging a passageway in the soft forest floor beneath. The truck was then driven under the great log and the latter lowered into place. Next came the task of drying out the body without "checking," to get rid of surplus weight. This was accomplished by sealing all apertures and turning on a sprinkler for two weeks. This washed out the sap and hastened the seasoning process. At the end of the two weeks the log had lost 1,200 pounds in weight.

Mr. Kellogg, himself, cut the windows and planned the interior. He found places for two beds, a kitchenette, a yacht lavatory, closets, electric fixtures and wiring. Then came some exquisite cabinet

Interior of the redwood-tree car being a small fireplace.

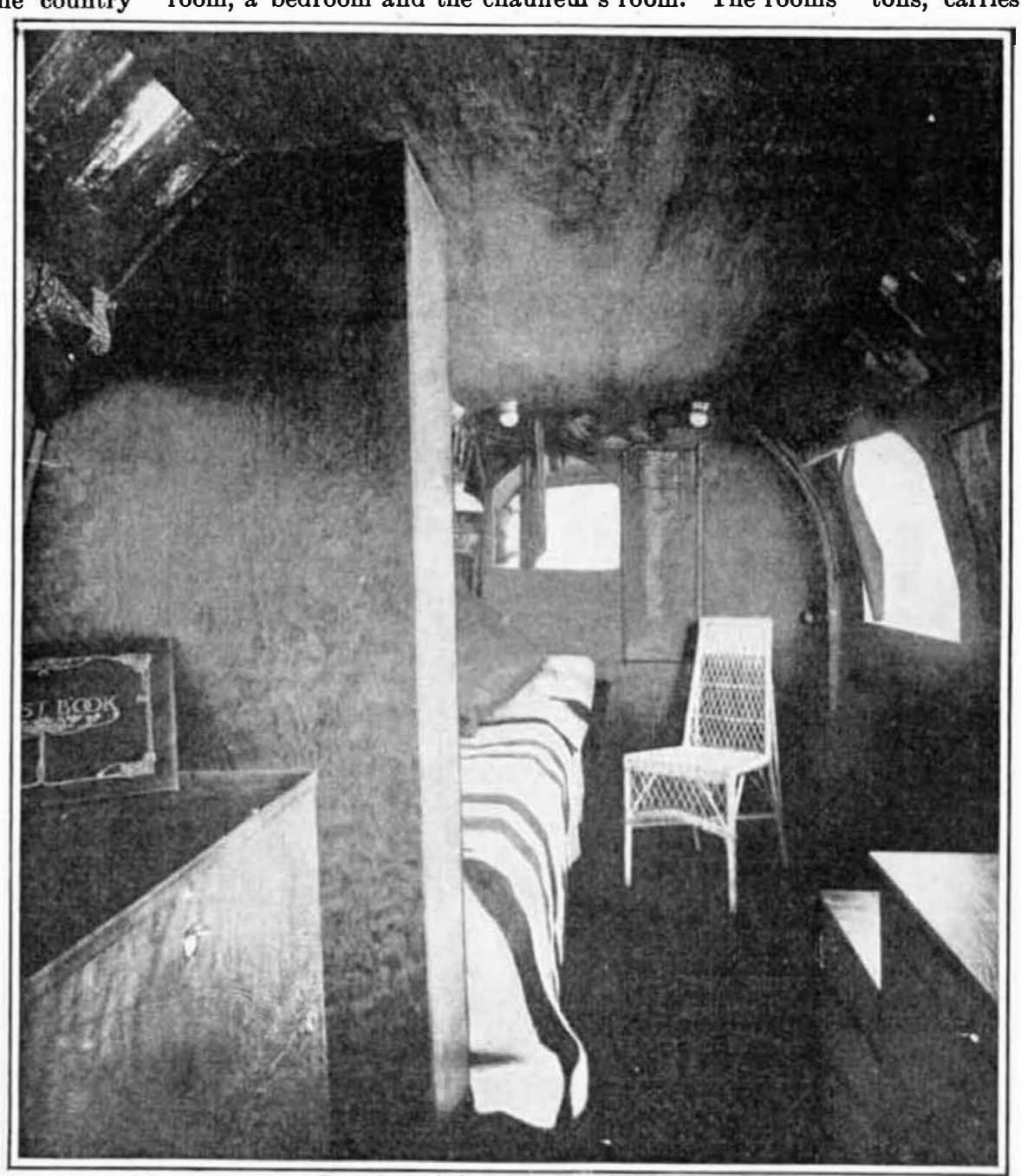

the Japanese universities had invented a successful in it, combustible substitute for celluloid, to be manufactured from soya bean cake. At the same time it was found impracticable to secure any more denite information with regard to the project, but recently further data have been received by the Bureau of Foreign and Domestic Commerce. The new product has been given the trade name of "Satolite," derived from the name of the inventor, Prof. S. Sato, and a company for its manufacture has been started with a capital of $2,000,000$ yen $(\$ 1,000,000)$. Satolite is a galalith made of the glucine of soya bean, coagulated by formaline. It is said to be produced much more cheaply than ordinary celluloid, and to have several advantages for industrial use not possessed by the latter. The factory is to be built in the Mukojima district in Toyko, and the actual production will begin this autumn.

The snow slid slowly down this garage roof to the position shown, where it remained several days 